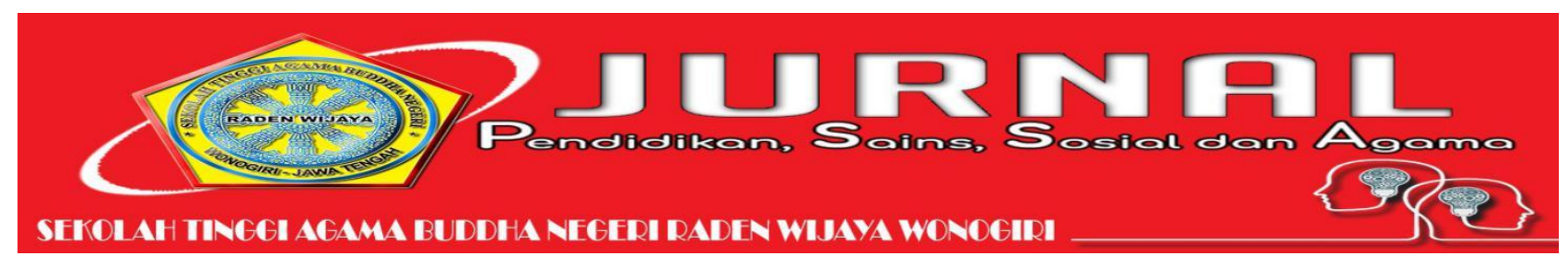

\title{
PETILASAN KAHYANGAN: MEMORY, SEJARAH DAN WISATA DI PINGGIRAN WONOGIRI
}

\author{
Andriyanto \\ Prodi Pendidikan Sejarah Univet Bantara Sukoharjo \\ Andri_rey@yahoo.co.id
}

\begin{abstract}
Abstrak
Penelitian ini mengkaji mengenai titik simpang antara historiografi masa awal Hadiwijaya sebelum naik tahta dan juga memori atau cerita tutur yang berkembang di Kahyangan Dlepih. Penelitian ini menggunakan metode sejarah dengan pengumpulan sumber berupa historiografi tentang kawasan tersebut, memori kolektif dan juga perkembangan kawasan ini menjadi kawasan wisata. Terdapat perbedaan antara yang tertulis pada historiografi dan juga yang berkembang pada masyarakat pendukungnya mengenai narasi kawasn Kahyangan Dlepih. Pada memori dan juga cerita rakyat, kawasan ini dipercaya sebagai lokasi pertapaan Hadiwijaya dan diperkuat dengan adanya makam Nyai Puju, namun pada historiografi disebutkan jika lokasi pertapaan Hadiwijaya berada di lokasi lainya dan lokasi ini dianggap keramat karena pada lokasi ini juga digunakan sebagai salah satu lokasi larung sesaji. Adanya narasi dan tradisi larung sesaji menyebabkan kawasan ini menjadi kawasan yang didatangi oleh para wisatawan religi.
\end{abstract}

Kata kunci: Kahyangan Dlepih, historiografi, memori, pariwisata

\begin{abstract}
This research examines the intersection point between Hadiwijaya's early historiography before ascending the throne and also the memory or speech stories that developed in Kahyangan Dlepih. This researchuses the historical method by collecting sources in the form of historiography about the area, collective memory and also the development of this area into a tourist area. There is a difference between what is written in historiography and what is developed in the supporting community regarding the narrative of the Dlepih Kahyangan area. In memory and also folklore, this area is believed to be the location of Hadiwijaya's hermitage and is strengthened by the tomb of Nyai Puju, but the historiography states that the location of Hadiwijaya's hermitage is in another location and this location is considered sacred because this location is also used as one of the larung locations. offerings. The existence of narratives and traditions of larung offerings causes this area to become an area visited by religious tourists.
\end{abstract}

Keywords: Kahyangan Dlepih, historiograpy, memory, tourism 


\section{PENDAHULUAN}

Kahyangan merupakan sebuah petilasan yang berada di Kecamatan Tirtomoyo, Kabupaten Wonogiri. Wilayah Wonogiri atau yang berada di daerah batas timur Sungai Keduwang merupakan kawasan yang berbatasan dengan wilayah mancanegara.(Margana 2010, 20) Kawasan ini merupakan kawasan yang disakralkan, karena kawasan ini diangap sebagai petilasan dari Panembahan Senopati. Panembahan Senopati melakukan topobroto di kawasan ini ketika akan menjadi Raja di Mataram.(Ramelan 1999, 3-4)

Adanya kepercayaan dari masyarakat pendukung kisah mengenai Panembahan Senopati yang mendapat wahyu dari Kahyangan Dlepih, menjadikan Kahyangan Dlepih sebagai magnet untuk menarik masyarakat untuk berkunjung, entah sebagai wisatawan, penikmat sejarah ataupun untuk ngalab berkah.

Penelitian yang khusus membahas mengenai sejarah, memori, dan pariwisata hanya terdapat beberapa saja. Kajian dari (Sakti 2015, 14-15) lebih banyak menjelaskan mengenai cerita rakyat dan juga wisata spiritual yang ditampilkan pada pertunjukan musikal. Kajian selanjutnya dari (Astuti 2020, 147) lebih banyak mengkaji mengenai ritual lelabuhan di Kahyangan Dlepuh. Tulisan mengenai cerita rakyat ditulis oleh (Quinn 2011, 147). Ritual lelabuhan di Kahyangan Dlepih juga diungkap pada tulisan
(Jalil 2015, 106). Tulisan lainya yang membahas mengenai Kahyangan Dlepih adalah tulisan dari (Ramelan 1999, 3-4), tulisan ini banyak mengkaji mengenai "masa lalu" dari Kahyangan Dlepih, namun demikian, pada buku ini tidak ada rujukan ataupun referensi lanjutan.

Historiografi nasional tidak banyak menempatkan Kahyangan Dlepih sebagai salah satu tempat penting dalam berdirinya Mataram. Tulisan dari (Graaf dan Pegeaud 2019, 381-82) menempatkan Kahyangan Dlepih sebagai salah satu tempat ritual pasca berdirinya Mataram Islam.

Penelitian mengenai historiografi tentang Kahyangan Dlepih masih terbatas pada cerita rakyat, sedangkan pada historiografi tidak begitu jelas menjelaskan mengenai kawasan ini dan hanya sebatas pada beberapa ritus yang dalam kepercayaan kekuasaan Jawa, kawasan ini dinilai sebagai kawasan yang memiliki nilai magis dan juga nilai "masa lalu" sehingga perlu dilakukan ritual tertentu.

Berangkat dari satu kisah mengenai Kahyangan sebagai tempat Panembahan Senopati mendapat wahyu di Kahayangan Dlepih, maka pada kajian ini akan diambil satu pertanyaan besar, yaitu bagaimana relasi hubungan antara memori masyarakat, narasi sejarah dalam grand naration mengenai Panembahan Senopati dan juga pengembangan wisata berbasis "sejarah". 


\section{METODE}

Guna membedah relasi antara ketiga konsep diatas, maka penelitian ini akan menggunakan penelitian sejarah dan memory. Penelitian sejarah untuk membedah narasi besar mengenai Panembahan Senopati dalam historiografi nasional, dan perkembangan Kahyangan Dlepih dalam perkembanganya sebagai objek wisata, sedangkan kajian memory digunakan sebagai pembanding mengenai narasi yang berkembang di masyarakat yang diwariskan secara turun temurun.

Adapun metode yang digunakan adalah pengumpulan data yang berupa tulisan sebelumnya mengenai Kahyangan Dlepih, cerita tutur ataupun memori yang diwariskan dan juga data perkembangan wisata di Kahayangan Dlepih, adapun data-data yang telah diperoleh kemudian dipilah, diinterpretasikan dan ditulis ulang. (Carr 2014, 4-6)

Penelitian ini akan membandingkan mengenai memori yang berkembang di masyarakat sekitar atau masyarakat pendukungnya dan juga data-data lainya dan dampaknya pada sektor wisatara religi.

\section{HASIL}

\section{Memori Masyarakat dan Pendukung Petilasan}

Ingatan Masyarakat merupakan

konsepsi dasar dari adanya cerita tutur sebelum cerita tutur tersebut tercampur bumbu-bumbu dalam perjalananya. Pada kasus ingatan masyarakat di Kahyangan
Dlepih satu cerita besar mengenai keberadaan dari Danang Sutawijaya yang kelak menjadi raja Mataram dengan Gelar Panembahan Senopati. Memory masyarakat Dlepih mengenai keberadaan petilasan Danang Sutawijaya diperkuat dengan beberapa tempat yang dianggap memiliki hubungan kuat dengan adanya ingatan yang berkembang.

Ingatan individu menjadi semakin kuat dengan adanya ingatan orang lain dalam kelompoknya. Ingatan yang berkembang di masyarkat akan menyebar dan mengakar pada individu yang berada dalam satu circle masyarakat tersebut.(Llobera 1995, 37) Ingatan masyarakat pendukung Kahyangan Dlepih yang mengkisahkan kawasan tersebut sebagai petilasan Danang Sutawijaya atau Panembahan Senopati terus direproduksi sehingga mempengaruhi ingatan individu.

Ingatan masyarakat yang diwariskan secara turun temurun menempatkan kawasan Kahyangan Dlepih sebagai tempat Danang Sutawijaya mendapat pulung atau mendapat restu untuk menjadi Raja Jawa. Beberapa titik dianggap sebagai situs pendukung atau penguat memori.

Penuturan dari Juru Kunci di Kahyangan Dlepih disebutkan jika Danang Sutawijaya menepi ke Kahyangan ketika terjadi kegelisahan di dalam sanubarinya. Danang Sutawijaya berusaha untuk menjadi penguasa dan menyatukan Tanah Jawa dibawah benderanya. Pada saat itu Mataram masih menjadi vasal dari Pajang. Danang Sutawijaya berusaha mendapat ketenangan 
atau kekuatan magis saat menepi di Kahyangan Dlepih.(Warto, 2021)

Danang Sutawijaya melakukan pertapaan pertama di kawasan Kahyangan Dlepih di Selo Bethek. Selo Bethek berlokasi paling utara dari beberapa tempat pertapaan, namun pertapaan di Selo Bethek tidak membuahkan hasil, kemudian berpindah di sebelah selatan, yaitu Selo Payung. Pada pertapaan di Selo Payung, Sutawijaya bertemu dengan Nyai Widononggo. Nyai Wodonggo merupakan suruhan dari Nyai Loro Kidul. Nyai Widononggo melakukan bisikan gaib kepada Sutawijaya untuk melakukan mandi di Kedung Pasiraman yang letaknya diatas Selo Payung. Setelah Sutawijaya di Kedung Pasiraman, maka pada saat itu bertemu dengan Nyai Loro Kidul.(Warto, 2021)

Pertemuan antara Hadiwijaya dengan Nyai Loro Kidul bukan hanya sebuah pertemuan biasa, namun terdapat ikatan atau janji sejak saat itu, yaitu janji pernikahan dan juga "transfer kekuatan". Penguasa Pantai Selatan tersebut memberikan kekuatan magis kepada Hadiwijaya dan juga seluruh keturunan yang kelak menjadi penguasa Tanah Jawa.(Ramelan 1999, 4-5)

Lebih lanjut dalam memory masyarakat tertanam satu tokoh lain yang menjadi sesepuh atau punden Desa Dlepih. Nyai Puju merupakan wanita desa yang telah bersuami, namun pada saat Sutawijaya bertapa, Nyai Puju berperan sebagai penyedia kebutuhan dan melakukan tindakan serong dengan Sutawijaya. Selepas pertapaan Sutawijaya, dan menjadi Raja Jawa Nyai Puju diangkat sebagai sesepuh atau yang menguasai Kahyangan Dlepih dan secara magis dilindungi atau dijaga oleh Nyai Widononggo.(Ramelan 1999, 6-10)

Ingatan masyarakat mengenai keberadaan Nyai Puju sebagai tokoh pelayan dan diangkat sebagai penjaga Kahyangan Dlepih diperkuat dengan adanya makam Nyai Puju di dekat kawasan petilasan. Makam ini menjadi penguat memory dan klaim kawasan Kahyangan Dlepih merupakan petilasan yang diskralkan.

Tempat tempat di Kahyangan Dlepih yang dianggap sebagai tempat ritual dari Danang Sutawijaya ketika menepi di Kahyangan Dlepih antara lain:

1. Sela Betek

2. Sela Gapit/ Penangkep

3. Sela Payung

4. Sela Gilang/ Pesalatan

5. Sela Gawok

6. Pemandian Kahyangan (Kedung= pertemuan 2 arus sungai).

Tempat-tempat diatas dipercaya memiliki makna atau kekuatan magis tersendiri. Selo Payung dipercaya memiliki kekuatan magis paling besar dan pada titik ini biasanya dijaga oleh juru kunci. Titik selanjutnya yang dianggap memiliki kekuatan magis yaitu Kedung Pasiraman dan Selo Bethek.

Memory masyarakat yang diwariskan secara turun-temurun mengenai lokasi 
Danang Sutawijaya mendapat wahyu, juga ditemukan di tempat lain, lebih lanjut baca pada sub bab selanjutnya. Terdapat dua tempat yang "diklaim" oleh masyarkat pendukungnya sebagai tempat Danang Sutawijaya mendapat wahyu dengan beberapa tempat yang menguatkan ingatan masyarakat.

Mengutip dari konsepsi memory yang cetuskan oleh Halbwachs, ingatan kolektif dari setiap kelompok masyarakat berbeda, hal ini didasarkan karena "pembangunan" atau penancapan memory. Penancapan memory oleh kelompok ditujukan untuk mengingat atau merayakan kembali masa lalu atau kenangan/ perayaan masalalu.(Llobera 1995, 37)

Peran memory kolektif masyarakat tentang keberadaan Danang Sutawijaya atau Panembahan Senopati yang "mendapat power" di daerah tempat tinggalnya dimaksnai oleh masyarakat sebagai kawasan yang "bertuah" atau sebagai legitimasi untuk menjadikan kawasan tersebut sebagai kawasan "yang disegai" terlebih ditambah dengan ritual rutin dari penguasa.

\section{Panembahan Senopati dalam Narasi Besar}

Kemunculan Mataram (Islam) tidak bisa dilepaskan dari kemunduran dan perpecahan dari dalam tubuh istana Demak. Istana Demak yang merupakan kerajaan Islam Tertua di Jawa mengalami masa surut ketika terjadi perpecahan. Kalangan istana mengalami perpecahan sampai puncaknya pusat pemerintahan berpindah atau masuk pada era baru di Pajang. (Ricklefs 2010, 96-
97; Kartodirjo 1999, 64; Graaf dan Pegeaud 2019, 360-64)

Kemunculan Mataram bersamaan dengan Pajang. Namun demikian, daerah Mataram merupakan daerah bawahan atau vasal dari Pajang. Kemunculan Mataram karena hadiah dari Jaka Tingkir, Raja Pajang, kepada Ki Ageng Pamanahan yang telah membantu "menyelesaikan" konflik di Demak.(Ricklefs 2010, 97; Lombard 2005, 36) ${ }^{1}$

Senopati menggantikan ayahnya, Pamanahan sebagai penguasa Mataram, yang masih dibawah kekuasaan Pajang pada tahun 1576.(Kartodirjo 1999, 126) Mulai saat itu pengaruh dari Senopati sebagai raja kecil di selatan Jawa mulai tumbuh, dan mencoba terus melebarkan pengaruh kekuasaanya.

Lebih lanjut, dalam tulisan dari Riclefs disebutkan jika anak Pamanahan, Senopati berambisi untuk membalikan kedudukan Pajang, Senopati menginginkan Mataram sebagai pusat kerjaan terkuat di Jawa. Lebh lanjut dalam usaha merebut kekuasaan dari Pajang, Senopati melakukan ritual di Selo Gilang (Jogjakarta) dan bertemu dengan Nyai Loro Kidul dan mendapat "restu" sebagai penguasa di Tanah Jawa.(Ricklefs 2007，97-98) Tulisan dari Sartono juga disebutkan adanya "pertemuan" antara Senopati dengan Nyai Loro Kidul, pada pertemuan tersebut, Senopati mendapat pulung yang menjadikan legitimasi maju

\footnotetext{
${ }^{1}$ Kerjaan Pajang hanya bertahan dari 1565-1586, dan statusnya berubah menjadi Vasal Mataram
} 
sebagai penguasa Jawa.(Kartodirjo 1999, 126-27)

Pada tulisan dari de Graaf dan Pigeaud juga dituliskan mengenai relasi antara Raja Jawa, terutama yang berkuasa di selatan Jawa, memiliki relasi "magis" dengan Nyai Loro Kidul. Hubungan antara Raja Jawa dengan penguasa Laut selatan merupakan tradisi dari zaman pra Islam yang masih berkembang sampai zaman Mataram. Hubungan antara Senopati dengan penguasa pantai selatan dilanjutkan ketika menjadi raja dan keturunannya untuk melakukan ritual ditemat-tempat yang dianggap memberikan power di Pantai Selatan Jawa, Gunung Lawu, Gunung Merapi, dan juga di Kahyangan Dlepih.(Graaf dan Pegeaud 2019, 381-82)

Kahyangan Dlepih pada tulisan Graaf dan Pigeaud dituliskan sebagai tempat pemujaan kepada Sungai Bengawan Solo. Terdapat kesalahan tafsir pada tulisan tersebut, kawasan sungai di Kahyangan Dlepih merupakan jalur sungai Wiroko, bukan Jalur Bengawan Solo meskipun pada akhirnya akan bertemu dengan jalur Sungai Bengawan Solo.

Tindakan "magis" Senopati untuk mendapat power atau kekuasaan di Tanah Jawa yang terekam dalam beberapa historiografi merupakan salah satu sisi local wisdom yang ada di Jawa sebagai langkah mendapatkan legitimasi dari sisi kepercayaan masyarakat. Kepercayaan masyarakat tentang "dunia lain" yang harus ditaklukkan atau harus memberikan restu kepada penguasa adalah pola pikir masyarakat yang akan dilewati penguasa untuk mendapatkan pengikut atau pengaruh.

Sartono menyebutkan jika hal-hal yang berbau mistis dalam hal kekuasaan Jawa disebut dengan mentifact. Kepercayaan masayrakat pendukung tentang menttifact yang telah dialami oleh Senopati menjadi dasar yang kuat untuk mendapaykan kekuasaan yang sah di Tanah Jawa.(Kartodirjo 1999, 127)

Faktor lainya yang menyebabkan naiknya Sutawijaya sebagai penguasa Tanah Jawa adala faktor ekonomi. Sutawijaya berhasil membendung pengaruh kekuasaan pajang terhadap daerah pendukungnya dan memberhentikan laju ekonomi menjadi salah satu penyebab naik tahta Sutawijaya menjadi penguasa baru di Tanah Jawa. (Purwanto 2017, 267-68)

\section{Wisata}

Kisah Senapati di Kahyangan Dlepih telah mengakar dan direproduksi turun temurun. Adanya kesamaan beberapa nama dan bentuk yang menjadi "properti kisah" menguatkan memory masyarakat pendukung. Nama-nama yang mengkisahkan pertemuan antara Senopati dengan penguasa laut selatan seperti batu-batu besar dan juga penyebutan nama Kahyangan menjadi penguat dari kawasan ini sebagai lokasi bertemunya Senopati dengan penguasa laut selatan.

Tulisan dari de Graaf dan Pigeaud menjelaskan jika terdapat memory yang sama di tempat lain, yaitu klaim batu yang 
dipercaya sebagai tempat bertemunya dua penguasa ini. Lebih lanjut, dalam kepercayaan yang beredar di Yogyakarta. Pada Memory yang ada di Yogyakarta disebutkan jika Senopati mendapat wahyu ketika di batu datar di Lipura setelah mendapat bisikan dari kahyangan, namun disitu tidak dijelakan lebih jauh relasi antara kahyangan yang dimaksud apakah kahyangan yang berada di Dlepih atau bukan.

Meskipun terdapat dua klaim lokasi Senopati bertemu dengan Nyai Loro Kidul, namun kedua tempat tetap diyakini oleh masyarakat pendukungnya sebagai tempat yang membawa aura dan diperkuat dengan adanya situs yang tetep dijalankan oleh keraton.

Ingatan masyarakat pendukung ditambah dengan adanya site of memory menjadi magnet tersendiri dari Kahyangan Dlepih untuh menggeret orang datang ke Kahyangan. Kahyangan Dlepih menjadi salah satu kawasan wisata "religi" ataupun wisata alam. Pesona magis ditambah dengan alam yang menggoda menjadikan kawasan ini sebagai salah satu destinasi wisata di Wonogiri.

Kawasan Kahyangan memiliki magnet wisata religi atau sejarah. Pada uraian diatas terdapat beberapa benang merah antara memory masyarakat pendukung dan juga yang terdapat pada narasi besar historiografi Indonesia. Kahyangan Dlepih menjadi salah satu peninggalan atau situs awal terbentuknya pemerintahan Mataram Islam.
Keberadaan situs atau punden Kahyangan Dlepih terus diuri-uri oleh pihak istana dengan dilakukan beberapa ritual pada tiap tahunnya dan juru kunci sebagaimana mengakar pada memory masyarakat "diakui" oleh pihak Keraton Ngayogjakarto sebagai abdi dalem istana. ${ }^{2}$

Keberadaan juru kunci yang "diakui" oleh pihak Kraton Ngayogjakarto semakin meyakinkan para pengunjung, terutama yang akan melakukan ritual di Kahyangan Dlepih. Juru Kunci ini ditugaskan secara khusus melakukan "pendampingan" ritual di Kahyangan Dlepih.(“Menapaki Kahyangan, Mengintip Babat Alas Kerajaan Mataram" 2019)

Hal yang menarik dari segi historis dari kawasan ini adalah pengangkatan juru kunci. Wilayah Tirtomoyo atau Wonogiri, ketika perjanjian pembagian kekuasaan antara Kasunanan dan Kasultanan Ngayogjakarta, wilayah ini merupakan wilayah kekuasaan Kasunan Surakarta, begitu pula ketika pembagian wilayah antara Kasunanan dengan Mangkunegaran, wilayah ini merupakan wilayah Mangkunegaran, namun kawasan petilasan menjadi dibawah kekuasaan dari Kasultanan.

Kawasan Kahyangan Dlepih yang memiliki nilai magis-historis ditambah dengan pemandangan alam menjadi salah satu objek wisata yang dikelola oleh Pemkab Wonogiri. Kahyangan dikelola sebagai tempat

\footnotetext{
2 Wawancara dengan Warto;("Mas Ngabehi Surakso Budoyo, Penjaga Situs Dlepih" 2018)
} 
wisata sejak 1983. Terdapat dualisme "pembagian kawasan". bagian bawah yang berhubungan dengan pariwisata dikelola oleh Dinas Pariwisata Kabupaten Wonogiri, sedangkan untuk juru kunci sebagaimana disebutkan diatas, juru kuncinya diangkat oleh Kraton Kasultanan. ${ }^{3}$

Lebih lanjut, dilahat segi estetika atau alam, kawasan Kahyangan Dlepih memiliki potensi alam yang menawan. Posisi Kahyangan Dlepih yang berada disebuah lereng bukit yang masih terjaga keasrianya menjadi sebuah public space atau sekedar mencari udara segar.

Tawaran lainnya yang menjadi daya tarik Kahyangan Dlepih adalah beberapa air terjun kecil dan juga sungai yang jernih bisa menjadi wisata air alami. Lebih lanjut di kawasan tersebut dijual berbagai souvenir dari batu akik. Batu dari kawasan Kahyangan Dlepih dipercaya memiliki "kekuatan". Potensi tersebut yang telah ditangkap oleh Dinas Pariwisata Kabupaten sejak tahun 1980an.

\section{KESIMPULAN}

Memory masyarakat tentang situs Kahyangan Dlepih beririsan dengan narasi besar yang ditulis pada Historiografi Nasional. Beberapa bagian menunjukkan hubungan saling menguatkan, namun pada beberapa bagian terdapat "miss".

\footnotetext{
${ }^{3}$ Wawancara dengan Kasdiyarjo, 30 Maret 2021
}

Beberapa hal yang dianggap memiliki relasi yaitu pada beberapa tulisan di narasi sejarah nasional disebutkan nama Kahyangan, dan pada tulisan dari de Graaf lebih jelas menyebut Kahyangan Dlepih sebagai salah satu tempat yang "dihormati", namun pada tulisan tersebut disebutkan jika Kahyangan Dlepih merupakan pemujaan atau penghormatan kepada sungai.

Pemujaan ataupun ritual di kawasan sumber mata air atau petirtan merupakan sebuah tradisi yang telah berjalan lama. Pada masa Hindhu-Buddha banyak dibangun bangunan suci untuk ritual di kawasan petirtan tersebut. Narasi mengenai petirtan juga diperkuat dengan adanya naskah Tantu Pagelaran.(Pradita dan Surya 2021, 22)

Memory masyarakat tentang situs petilasan Panembahan Senopati diperkuat dengan adanya makam di dekat situs. Makam Nyai Puju yang mengakar kuat dalam ingatan masyarakat menjadi penguat memori kolektif masyarakat.

Kuatnya memory di masyarakat menjadi magnet wisatawan "religi" atau ngalab berkah di Kahyangan Dlepih. Lebih lanjut terdapat potensi alam yang memanjakan mata wisatawan. Modal yang kuat untuk dijadikan kawasan wisata, Pemeritah Kabupaten Wonogiri mengelola dan mengembangkan kawaasan Kahyangan Dlepih sebagai kawasan wisata "religi" dan wisata alam.

\section{Daftar Pustaka}


Astuti, Widhi. 2020. "BENTUK PENDIDIKAN KARAKTER DI KARATON KASUNANAN SURAKARTA BERBASIS AJARAN TRI HITA KARANA.” Widya aksara 25 (1).

Carr, E.H. 2014. Apa Itu Sejarah. Depok: Komunitas Bambu.

Graaf, H.J. de, dan TH.G. TH. Pegeaud. 2019. Kerjaaan Islam Pertama di Jawa Tinjauan Sejarah Politik Abad XV dan $X V I$. Yogyakarta: Mata Bangsa.

Jalil, Abdul. 2015. "MEMAKNAI TRADISI UPACARA LABUHAN DAN PENGARUHNYA TERHADAP MASYARAKAT PARANGTRITIS.” $e l$ Harakah 7 (1).

Kartodirjo, Sartono. 1999. Pengantar Sejarah Indonesia Baru 1500-1900. Jakarta: Gramedia Pustaka Utama.

Llobera, Joseph R. 1995. "Halbwachs, Nora and 'history' versus 'collective memory': a research note." Durkheimian Studies / Études Durkheimiennes 1.

Lombard, Denys. 2005. Nusa Jawa: Silang Budaya Warisan Kerajaan Konsentris. Jakarta: Gramedia Pustaka Utama.

Margana, S. 2010. Kraton Surakarta dan Yogyakarta. Yogyakarta: Pustaka Pelajar.

"Mas Ngabehi Surakso Budoyo, Penjaga Situs Dlepih.” 2018. Kraton Jogja. 2018. https://www.kratonjogja.id/ragam/12/ma s-ngabehi-surakso-budoyo-penjaga-situsdlepih.

"Menapaki Kahyangan, Mengintip Babat Alas Kerajaan Mataram.” 2019. Humas Jateng. 2019. https://humas.jatengprov.go.id/detail_ber ita_gubernur?id=2724.

Pradita, Dennys, dan Adi Putra Surya. 2021. "Islam dan Kejawen pada Ritual Bersih Desa di Giriwoyo, Wonogiri pada Masa Pandemi." Jurnal Sahdu 1 (2).

Purwanto, Bambang. 2017. "Memperebutkan Wahyu Majapahit dan Demak: Membaca Ulang Jejak Kesultanan Pajang." Patrawidya 18 (3).
Quinn, George. 2011. "Washing your hair in Java." In And Culture.

Ramelan, M. 1999. Petilasan Pertapaan Kahyangan Dlepih. Surakarta.

Ricklefs, M..C. 2007. Sejarah Indonesia Modern 1200-2008. III. Jakarta: Serambi.

Ricklefs, M.C. 2010. Sejarah Indonesia Modern: 1200-2008. Jakarta: Serambi.

Sakti, Reza Ginandha. 2015. "KAHYANGAN: SEPENGGAL KISAH DALAM LEGENDA PERADABAN TANAH JAWA DALAM KOMPOSISI MUSIKAL." Dewaruci 10 (1).

Wawancara

1. Warto, 2021 